\title{
Land use change in the Veneto floodplain and consequences on minor network drainage system
}

\author{
Massimo Prosdocimi, Giulia Sofia, Giancarlo Dalla Fontana, Paolo Tarolli \\ Department of Land, Environment, Agriculture and Forestry, University of Padova, Agripolis, \\ Legnaro, (PD) Italy
}

\begin{abstract}
Anthropic pressure has been proven to be one of the most evident forces able to alter landscapes. Its impact on the surroundings can be easily detectable especially in a high-density populated country such as Italy. Among the most evident anthropic alterations, the most important are the urbanization processes but also changes in cultural techniques that have been occurring in rural areas. These modifications influence the hydrologic regimes in two ways: by modifying the direct runoff production and by having a strong impact on the drainage system itself. The main objectives of this work are to evaluate the impact of land cover changes in the Veneto region (north-east Italy) on the minor drainage network system, and to analyze changes in the direct runoff in the last $\mathbf{5 0}$ years. The study area is a typical agrarian landscape and it has been chosen considering its involvement in the major flood of 2010 and considering also the availability of data, including historical aerial photographs, historical information, and a high resolution LiDAR DTM. The results underline how land cover variations over the last 50 years have strongly increased the propension of the soil to produce direct runoff (increase of the Curve Number value) and they have also reduced the extent of the minor network system to the detriment of urbanized areas and changes of plots of land boundaries. As a consequence, the capacity of the minor network to attenuate and eventually laminate a flood event is decreased as well. These analysis can be considered useful tools for a suitable land use planning in flood prone areas.
\end{abstract}

Correspondence: Paolo Tarolli, Dipartimento Territorio e Sistemi AgroForestali, Università degli Studi di Padova, Viale dell'Università 16, 35020 Legnaro (PD), Italy. E-mail: tarolli.paolo@gmail.com

Key words: land cover change, direct runoff, DTM, minor network system.

Acknowledgements: LiDAR data were provided by the Ministry for Environment, Land and Sea (Ministero dell'Ambiente e della Tutela del Territorio e del Mare, MATTM), within the framework of the 'Extraordinary Plan of Environmental Remote Sensing' (Piano Straordinario di Telerilevamento Ambientale, PST-A).

(C) Copyright M. Prosdocimi et al., 2013

Licensee PAGEPress, Italy

Journal of Agricultural Engineering 2013; XLIV(s2):e90

doi:10.4081/jae.2013.s2.e90

This article is distributed under the terms of the Creative Commons Attribution Noncommercial License (by-nc 3.0) which permits any noncommercial use, distribution, and reproduction in any medium, provided the original author(s) and source are credited.

\section{Introduction}

Significant changes in land use happened over the last few centuries in all European countries and whether the floods experienced in these recent years are triggered or exacerbated by human activities, has been subject of much debate (Bronstert, 1996; Kundzewicz and Takeuchi, 1999; Kundzewicz and Kaczmarek, 2000; Longfield and Macklin, 1999). Alterations in agricultural techniques and the simultaneous increase of urbanization and industrialization processes have increased the extent of impervious areas, causing the so-called soil sealing. Leopold in 1968 demonstrated that passing from a permeable soil type (i.e. grassland) to a less permeable one (i.e. urbanized area), a faster and higher response of the watershed in generating runoff is expected and thus, a clear modification in the hydrograph shape. As outlined by Bronstert et al. (2001), both runoff generation and discharge conditions can be altered by human activities and, in general, field drainage, wetland loss and urbanization result in increased 'flashiness' of runoff, more rapid downstream transmission of flood waves, and less floodplain storage. Recently, Veneto Region has undergone both significant territorial and socio-economic changes. Actual conformation arises due to the expansion of a metropolitan polycentric system, characterized by a dispersion of low-density residential functions and a homogeneous distribution of medium-small size productive activities (Fregolent, 2005). These dispersion processes have been deeply studied since the $80 \mathrm{~s}$ and a particular attention has been given to the phenomenon called "urban sprawl" (Indovina 1990, 2009; Indovina, Fregolent, Savino 2004; Tosi, Munarin 2004; Fregolent 2005, 2012). This process caused the expansion of new residential neighborhoods and productive/commercial areas to the detriment of agricultural plots. Therefore, in the floodplain context, the natural river system has been deeply modified over time through the artificial management of water levels and discharges. This resulted in an artificial drainage system, in which the flow occurs along a network of regular channels (larger channels and small ditches), often through water pumping. There is no doubt that this type of area is naturally exposed to the danger of floods, whose causes are multiple and often interacting with each other. The principal causes can be generally distinguished between problems related to large rivers unable to manage the incoming flows, and issues directly related to the inability of draining meteoric water through the smaller hydraulic network (ditches). While problems related to the large rivers are mainly connected to choices and actions applied in historical times, the problems of the smaller hydraulic network are due to small and relatively recent territorial changes: fast human settlement in floodplain, and the intense urbanization, have reduced the extent of the network while increasing at the same time impermeable surfaces, with the result that the remaining network drainage capabilities are no longer sufficient (Cazorzi et al., 2013). As a consequence, situations of hydraulic crisis happen with increasing frequency and they affect the most urbanized districts.

This work aims to analyze the effects of land use cover changes, 
occurred in the Veneto region over the past 50 years, on the minor drainage network system and direct surface runoff. The study area has been selected because of its involvement in the major flood of 2010 and because of the availability of data, including historical aerial photographs, historical information, and a high resolution LiDAR Digital Terrain Model (DTM). In particular, many recent studies have proved the reliability of these models in many disciplines concerned with Earth-surface representation and modeling, including applications in hillslope (Tarolli and Tarboton, 2006; Lashermes et al., 2007; Booth et al., 2009; Kasai et al., 2009; Tarolli and Dalla Fontana, 2009; Orlandini et al., 2011) and fluvial environments (Charlton et al., 2003; Heritage and Hetherington, 2007; Hilldale and Raff, 2008; Jones et al., 2007; Cavalli et al., 2008; Vianello et al., 2009; Notebaert et al., 2009; Cavalli and Tarolli, 2011; Legleiter, 2012; Cazorzi et al. 2013). There is also a growing interest in the application of such information by agencies responsible for land management for the development of automated methods aimed at solving geomorphological and hydrological problems. Automatic feature extraction from LiDAR DTMs can in fact greatly improve databases and it is a useful tool for natural hazard mapping and environmental planning.

\section{Materials and methods}

The study is based on the availability of historical aerial images that date back to 1954, 1981 and 2006 and a high resolution LiDAR DTM having $1 \mathrm{~m}$ cell size. At first, a semi-automatic approach, developed by Cazorzi et al., 2013, has been applied in order to identify the minor drainage network system and estimate some its parameters such as drainage density and storage capacity, through the DTM which dates back to 2006 and a morphological parameter named Relative Elevation Attribute (REA) derived from it. A thresholding approach based on the standard deviation of REA has been used in order to automatically extract the small-scale topography features (minor drainage network system) (Figure 1).

The procedure divides the area in analysis in square sub-areas whose each one is $100 \mathrm{~m} \mathrm{x} 100 \mathrm{~m}$ wide. For each sub-area, are computed the average width of ditches, drainage density and storage capacity values.

Based on the relative available historical images, land use cover maps and drainage network systems have been both drawn. Due to the mediocre resolution and due to black and white colors of the images of 1954 and 1981, it has been possible to identify only two macro-cate- gories of land use cover: agricultural lands and artificial surfaces. For uniformity, such classification has been applied to 2006 as well, although more detailed information were available thanks to the CORINE land cover data. In order to avoid as much as possible misleading identifications, local authorities, such as the Adige-Euganeo Land Reclamation Consortium, and local farmers were interviewed and shown, as validation, the likely land use cover and minor drainage network maps (Figure 2).

By knowing the likely length of the minor drainage network, it has been possible to estimate the variation of drainage densities over time.

By applying the Soil Conservation Service Method (USDA, 1972), such land use cover maps have been combined with data concerning the hydrological soil groups made available by Veneto Region, in order to obtain Curve Number maps for 1954, 1981 and 2006. Since precise CN values did not exist for the land cover categories identified in the study area, such values have been obtained by averaging plausible values concerning artificial surfaces and agricultural lands found in literature. Still according to the SCS-CN method, direct surface runoff has been computed for each year by considering a uniformly distributed rainfall over the study area. Maximum rainfall values for different return times (2, 5, 10, 30, 50, 100 and 200 years) and durations ( 1 and 3 hours) registered at the meteorological station of Este, have been used for the aforementioned purpose.

The effects of drainage network storage capacity on direct runoff from 1954 to 2006 have been analyzed through the application of the so-called "Residual runoff" index ( $\left.\mathrm{m}^{3} / \mathrm{ha}\right)$ (Eq.1):

$$
\text { Residual runoff }=\text { Direct runoff }- \text { Storage capacity }
$$

The aforementioned index has been computed for each $100 \mathrm{~m}$ x 100 m square sub-area.

Since the semi-automatic approach, which has been applied for the 2006 , gives, as output for each cell, also the average width and the consequent average cross section area of ditches, it has been possible to estimate the likely storage capacity for 1954 and 1981 as well, by simply multiplying the ditches length by the cross section areas for that cell. For this analysis, the upstream contributions are not accounted for because this assessment aims to identify the presence of areas that may be already in critical condition for the runoff directly produced by the input local rainfall.

\section{Study area}

The study site is a small area covering about 266 ha and it is located within a flooded area identified according to warnings made by people

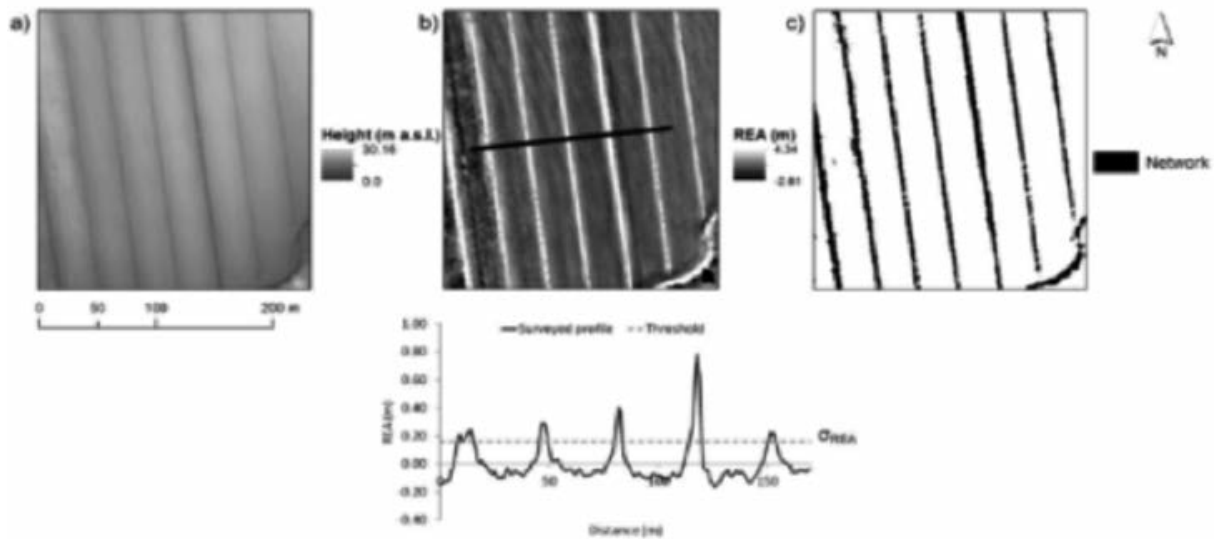

[Journal of Agricultural Engineering 2013; volume XLIV(s2):e90]
Figure 1. a) Input DTM, b) derived REA map and the threshold identified (standard deviation of REA) to detect the network, c) boolean map obtained from the methodology applied where features can take only binary values: 1 or 0 for network and landscape pixels respectively (modified from Sofia, 2012). 
during the major Veneto flood event of 2010. It is placed between the municipalities of Montagnana and Megliadino San Fidenzio (province of Padua), and it is about $12 \mathrm{~km}$ far from the meteorological station of Este (Figure 3).

The area belongs to the Brenta-Bacchiglione River Basin Authority and it is located within the boundaries of the Adige-Euganeo Land Reclamation Consortium. Other than for its involvement in the major flood event, the study area has been selected also for the availability of LiDAR DTM and historical images (1954, 1981 and 2006) and because it is a representative of a typical Veneto agrarian landscape.

\section{Results}

Land use cover has undergone significant changes from 1954 to 2006. Artificial surfaces increased in extension passing from 16.02 ha in 1954 to 87.57 ha in 2006 to the detriment of agricultural lands. As a consequence, reductions of drainage network length, drainage density and storage capacity values have been registered as well (Table 1 and Figure 4 and 5).

Concerning the effects of drainage network storage capacity on direct runoff, by return times greater than 10 years direct runoff values get much larger than storage capacity ones; therefore, residual runoff index starts to lose his meaning. Hence, it is possible to declare that ditches become critical because they already get saturated by considering as input a local rainfall with return times greater than 10 years and 1 hour duration. Given the definition of residual runoff, as it gets higher it corresponds to a worsening of the situation (increase in impermeable surfaces) and thus, we move from 1954 to 2006 and vice versa (Figure 6).

\section{Conclusions}

This study highlighted the influence of land use changes on drainage network systems and direct runoff. Since drainage networks in agrarian landscapes within floodplains are expected to affect hydrological response during floods (Cazorzi et al., 2013), this assessment becomes a crucial tool for flood management. In fact, low values of

Table 1. Table reporting values concerning the variation of land use change, drainage network system, drainage density and storage capacity from 1954 to 2006.

\begin{tabular}{lcccc} 
& & 1954 & 1981 & 2006 \\
Land use cover (ha) & Artificial surfaces & 16.02 & 40.95 & 87.57 \\
& Agricultural lands & 249.98 & 225.05 & 178.43 \\
Drainage network system $(\mathrm{km})$ & 58.70 & 47.13 & 30.08 \\
Drainage Density $\left(\mathrm{km}^{\mathrm{k}} \mathrm{km}^{2}\right)$ & 22.07 & 17.72 & 11.31 \\
\hline Storage capacity $\left(\mathrm{m}^{3} \mathrm{ha}\right)$ & 28600 & 23900 & 18290 \\
\hline
\end{tabular}

a)

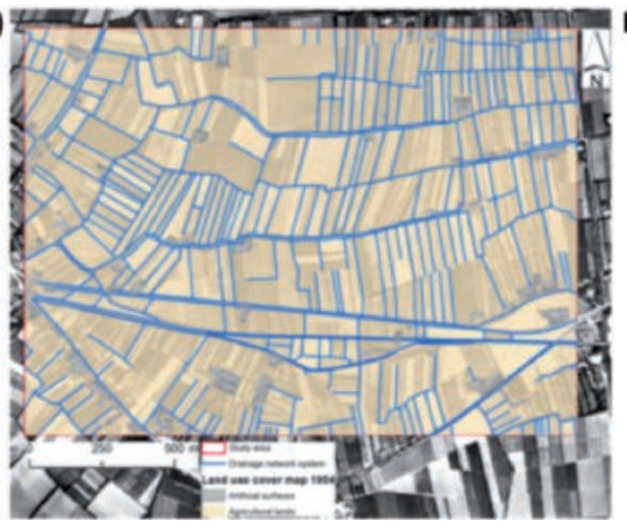

b)

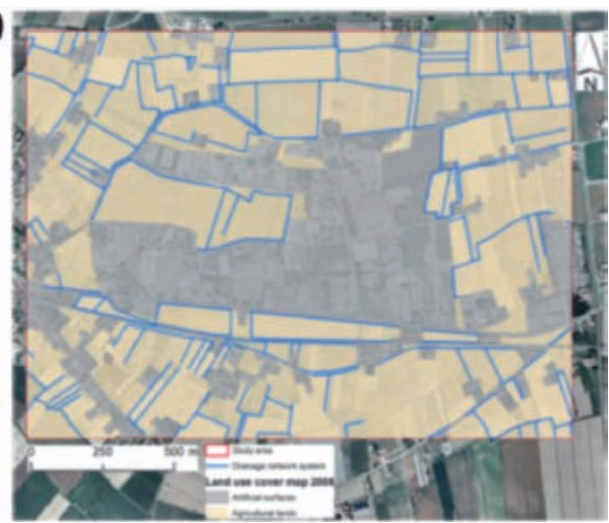

Figure 2. Land use cover maps and likely drainage network system in 1954 (a) and in 2006 (b). In yellowish are represented the agricultural lands while in grayish the artificial surfaces. Blue lines represent ditches and channels.

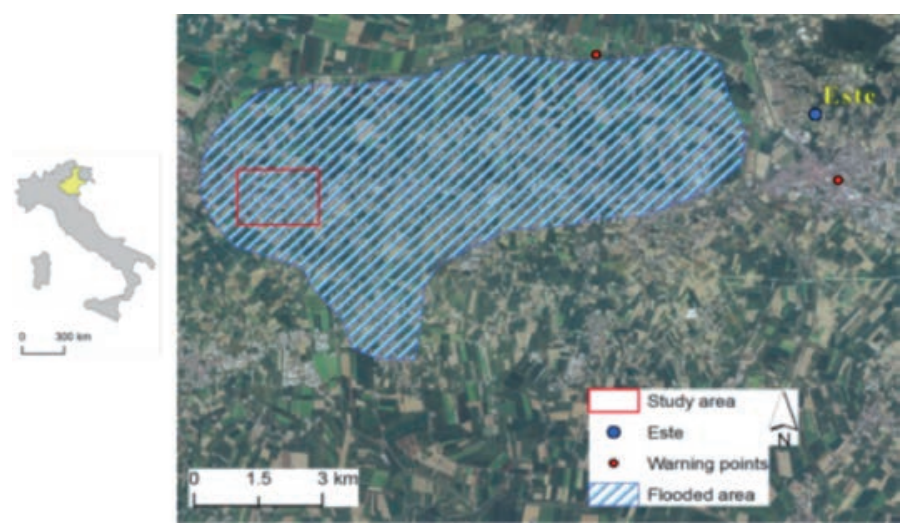

Figure 3. Localization of the study area. It has been selected because of its involvement in the major flood event of 2010. 
a)

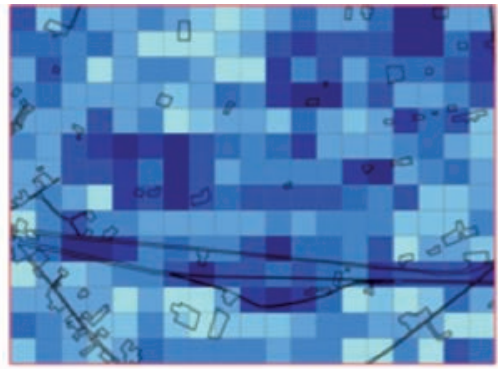

$250500 \mathrm{~m}$

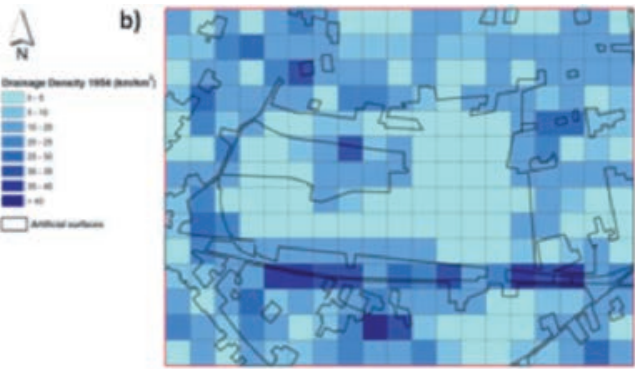

- $250500 \mathrm{~m}$

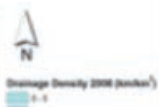

Figure 4. Drainage density maps computed for each sub area (1 ha) for 1954 (a) and 2006 (b). The color ranges from light blue (lower values) to dark blue (higher values). Moving from the 50's to the twenty first century an increase in number of lighter sub areas can be easily detected. a)
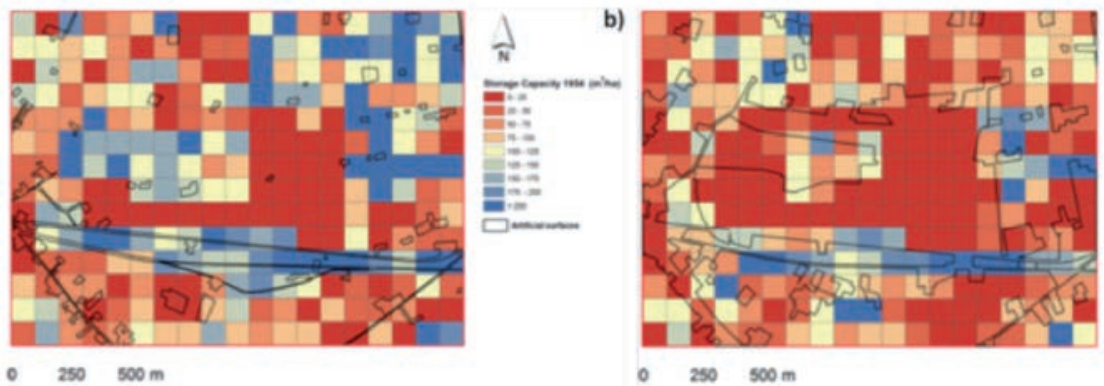

- $250 \quad 500 \mathrm{~m}$

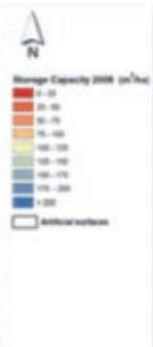

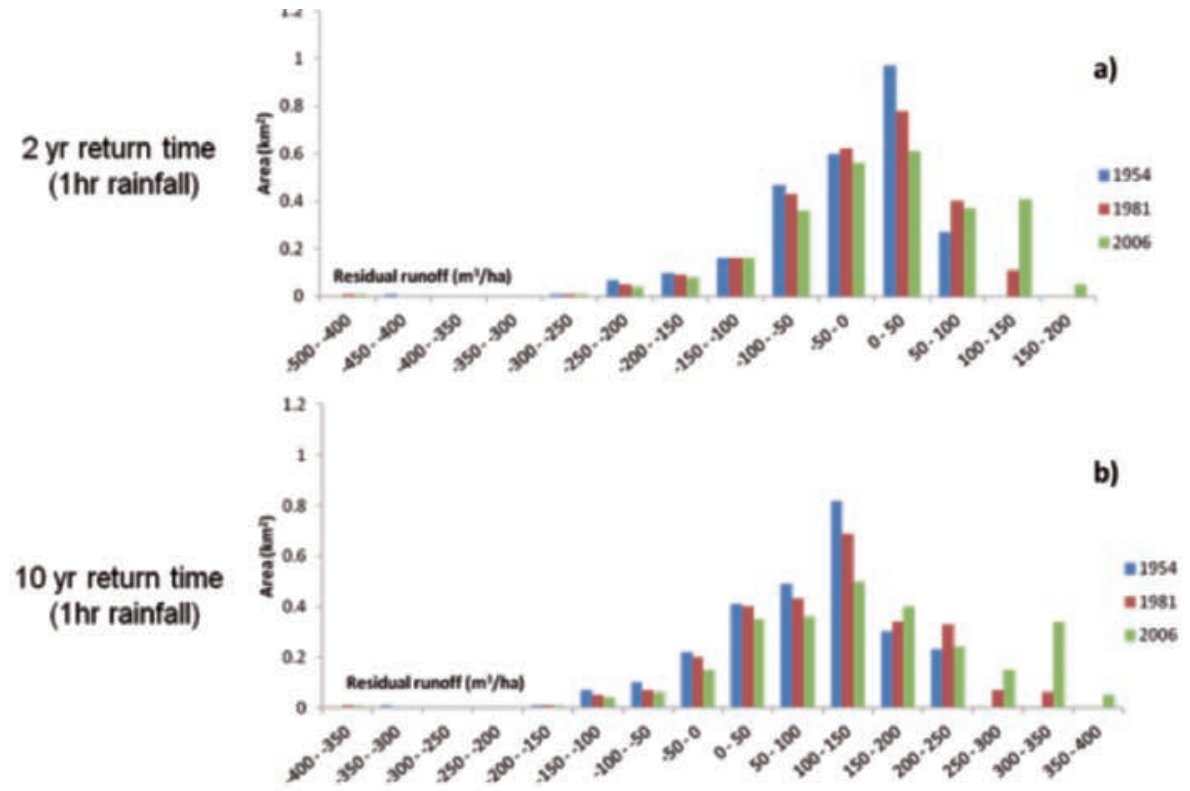

Figure 6. Comparison between the three mean residual runoffs computed for each sub area, by considering a rainfall with return times of 2 and 10 years and 1 hour duration. The lower are the values and the better is the situation from a hydrological point of view. By moving from a 2 years return time to a 10 years return time rainfall, higher residual runoff classes become more representative.

channel storage capacity can i) outline areas whose hydrological behavior is potentially critical during floods, where land use might increase the level of risk, and ii) they allow to identify storage volumes already available on the surface that can contribute to laminate flood peaks. Therefore this work provides an additional proof of suitability of the estimated network parameters (drainage density and storage capacity) in supporting flood management. In addition, by analyzing the effects of drainage network capacity on the direct surface runoff, it has been possible to evaluate the presence of areas that may be already risky simply for the runoff directly produced by the input local rainfall; in this perspective, a simple index (residual runoff) has been computed. As main outcomes, this work highlighted that: 1) there might be some issues in the network in the case of rainfall events with return times greater than 10 years and 1 hour duration, and 2) changes in land use should be accounted in planning and managing procedures. The increase of runoff due to land use change should always be accounted for, and it should be operationally compensated by a corresponding increase of the storage capacity. If this is not accomplished, 
an increase of the residual runoff should be expected, with problems related to its control, especially when dealing with floods.

\section{References}

Booth A.M., Roering J.J., Perron J.T. 2009. Automated landslide mapping using spectral analysis and high-resolution topographic data: Puget Sound lowlands, Washington, and Portland Hills, Oregon. Geomorphology 109: 132-147. doi:10.1016/j.geomorph.2009.02.027.

Bronstert A. 1996. River flooding in Germany: influenced by climatic change? Physics and Chemistry of the Earth 20(5-6): 445-450.

Bronstert A., Niehoff D., Burger G. 2001. Effects of climate and land-use change on storm runoff generation: present knowledge and modeling capabilities. Hydrological Processes 16: 509-529.

Cavalli M., Tarolli P., Marchi L., Dalla Fontana G. 2008. The effectiveness of airborne LiDAR data in the recognition of channel bed morphology. Catena 73: 249-260. doi:10.1016/j.catena.2007.11.001.

Cavalli M., Tarolli P. 2011. Application of LiDAR technology for rivers analysis. Italian Journal of Engineering Geology and Environment. Special Issue 1: 33-44. doi:10.4408/IJEGE.2011-01.S-03.

Cazorzi F., Dalla Fontana G., De Luca A., Sofia G., Tarolli P. 2013. Drainage network detection and assessment of network storage capacity in agrarian landscape. Hydrological Processes. 27(4): 541553. doi: 10.1002/hyp.9224.

Charlton M.E., Large A.R.G., Fuller I.C. 2003. Application Of Airborne LiDAR In River Environments: The River Coquet, Northumberland, Uk. Earth Surf. Process. Landforms 28: 299-306.

Fregolent L. 2005. Governare la dispersione. FrancoAngeli, Milano.

Fregolent L. 2012. La città a bassa densità: problemi e gestione. TeMA Journal of Land Use, Mobility and Environment, 5(1): 7-19.

Heritage G., Hetherington D. 2007. Towards a protocol for laser scanning in fluvial geomorphology. Earth Surf. Process. Landforms 32: $66-74$.

Hilldale R.C., Raff D. 2008. Assessing the ability of airborne LiDAR to map river bathymetry. Earth Surface Processes and Landforms 33: 773-783.

Indovina F. 1990. La città diffusa. Daest-IUAV, Venezia.

Indovina F., Fregolent L., Savino M. 2004. L'esplosione della città. Editrice Compositori, Bologna.

Indovina F. 2009. Dalla città diffusa all'arcipelago metropolitano. FrancoAngeli, Milano.

Jones A.F., Brewer P.A., Johnstone E., Macklin M.G. 2007. High resolu- tion interpretative geomorphological mapping of river valley environments using airborne LiDAR data. Earth Surface Processes and Landforms 21: 1574-1592.

Kasai M., Ikeda M., Asahina T., Fujisawa K., 2009. LiDAR-derived DEM evaluation of deep-seated landslides in a steep and rocky region of Japan. Geomorphology 113: 57-69.

Kundzewicz Z.W., Kaczmarek Z. 2000. Coping with hydrological extremes. Water International 25(1): 66-75.

Kundzewicz Z.W., Takeuchi K. 1999. Flood protection and management: quo vadimus? Hydrological Sciences Journal 44(3): 417-432.

Lashermes B., Foufoula-Georgiou E., Dietrich W.E. 2007. Channel network extraction from high resolution topography using wavelets. Geophysical Research Letters 34, L23S04, doi:10.1029/ 2007GL031140.

Legleiter C.J. 2012. Remote measurement of river morphology via fusion of LiDAR topography and spectrally based bathymetry. Earth Surface Processes and Landforms 37(5): 499-518.

Leopold B.L. 1968. Hydrology for Urban Land Planning - A Guidebook on the Hydrologic Effects of Urban Land Use. Geological Survey Circular 554. Washington.

Longfield S.A., Macklin M.G. 1999. The influence of recent environmental change on flooding and sediment fluxes in the Yorkshire Ouse basin. Hydrological Processes 13(7): 1051-1066.

Notebaert B., Verstraeten G., Govers G., Poesen J. 2009. Qualitative and quantitative applications of LiDAR imagery in fluvial geomorphology. Earth Surface Processes and Landforms 34, 217-231.

Orlandini S., Tarolli P., Moretti G., Dalla Fontana G. 2011. On the prediction of channel heads in a complex alpine terrain using gridded elevation data. Water Resources Research 47, W02538. doi:10.1029/2010WR009648.

Sofia G. 2012. Digital terrain analysis for hydrogeomorphic feature recognition. PhD Degree Diss., Università di Padova, Italy.

Tarolli P., Tarboton D.G. 2006. A New Method for Determination of Most Likely Landslide Initiation Points and the Evaluation of Digital Terrain Model Scale in Terrain Stability Mapping. Hydrology and Earth System Science 10: 663-677. doi:10: 663-677.

Tarolli P., Dalla Fontana G. 2009. Hillslope to valley transition morphology: new opportunities from high resolution DTMs. Geomorphology 113: 47-56.doi:10.1016/j.geomorph.2009.02.006.

Tosi M.C., Munarin S. 2004. Tracce di città. Esplorazioni di un territorio abitato: l'area veneta. FrancoAngeli, Milano.

Vianello A., Cavalli M., Tarolli P. 2009. LiDAR-derived slopes for headwater channel network analysis. Catena 76, 97-106. doi:10.1016/j.catena.2008.09.012. 